\title{
IVAN VIEN AND THE FIRST COMPREHENSIVE PLAGUE TRACTATE IN RUSSIAN
}

\section{J. T. ALEXANDER*}

IVAN IVANOVICH VIEN (c. 1750-1809) is not a well-known personage either in the history of Russia or the history of medicine. Indeed, most biographical dictionaries overlook him, and his date of birth remains unknown. ${ }^{1}$ Yet information will be presented here to contend that he was fairly prominent in the Russian medical world of his time, that his career elucidates important trends in the formation of the Russian medical profession, and that his principal scholarly work deserves serious study.

Before exploring Vien's career and writings, however, it may be instructive to speculate upon the reasons for his relative obscurity. Whatever eminence he achieved in Russia in his lifetime was not continued long and was not matched by recognition abroad. Though cosmopolitan in background and outlook, Vien never earned an advanced degree, never married, and apparently never travelled abroad. His modest origins, long military service, and middling bureaucratic rank conferred scant distinction. His primary claim to renown - authorship of the first comprehensive plague tractate in Russian - was little appreciated in his native land, where medical scholarship had scarcely begun, and even less noticed abroad because the Russian language enjoyed neither popularity nor respectability in European medico-scientific circles. Furthermore, his modest reputation suffered neglect in nineteenth-century Russia at the hands of nationalistic historians such as Dr. Ia. A. Chistovich, whose brief biographical sketch ignored Vien's major publication, implicated him in petty squabbles over pay and in disputes over the language of publication for Russian medical treatises, and concluded with the remark that he "never held the doctor's degree."2 Soviet historians of medicine mention Vien only to scoff at his ideas about

*J. T. Alexander, Ph.D., Department of History, University of Kansas, Lawrence, Kansas 66045 , U.S.A

${ }^{1}$ There is no entry for Vien in Bol'shaia meditsinskaia entsiklopediia, 2nd ed., vol. V, Moscow, Gosudarstvennoe izdatel'stvo meditsinsk oi literatury, 1958. In the standard pre-revolutionary biographical dictionary, Russkii biograficheskii slovar', the relevant volume was never published, but an earlier compendium contains a brief, defective entry: Azbuchnyi ukazatel imen russkikh deiatelei dlia russkogo biograficheskogo slovaria, St. Petersburg, 1887, pt. I, p. 106, (reprinted Nendeln/Liechtenstein, KrausThomson, 1976).

${ }^{2}$ Ia. A. Chistovich, Istoriia pervykh meditsinskikh shkol v Rossii, St. Petersburg, Tipografiia lakova Treia, 1883, app. X: 'Alfavitnyi spisok doktorov meditsiny, praktikovavshikh v Rossii v XVIII stoletii', pp. cxxii-cxxiv. In view of Chistovich's remark and the title of his biographical dictionary of "doctors of medicine who practised in Russia in the eighteenth century," it is curious that he saw fit to include Vien at all. 


\section{J. T. Alexander}

plague, which they usually dismiss in favour of the allegedly more "progressive" views of his contemporary rival, Danilo Samoilovich (1744-1805). As two examples, S. M. Grombakh deplored Vien's "caustic attacks" on Samoilovich, whereas A. I. Metelkin condemned Vien's own tractate: "This work, which has left few traces in the history of our epidemiology, as one would expect, strove to prove the bankruptcy of Samoilovich's views." ${ }^{3}$ Such simplistic criticisms demean both Samoilovich and Vien, whose plague tractates were appropriately displayed together at the Military-Medical Museum in Leningrad in 1975 - Samoilovich's with a laudatory caption, Vien's without comment.

\section{I}

Besides Vien's works (see appendix), the main sources bearing on his career are two "service lists" and a packet of promotion materials collected by the Ministry of Internal Affairs in 1805, now preserved in the Central State Historical Archives of the U.S.S.R. in Leningrad, and a petition of 1786 to Empress Catherine II in the Central State Archives of Old Documents in Moscow.4 Ia. A. Chistovich and B. N. Palkin consulted some of these records for summary sketches of Vien's life, but neither historian attempted any analysis of the bare biographical facts.s Although some details may be lacking, closer study of these materials can provide a fuller picture than was previously available.

Little is known about Vien's origins. He was born in Moscow about 1750 into the family of a schoolteacher according to Chistovich and Palkin, but the promotion materials of 1805 , which listed him as fifty-five years old, cryptically labelled him "the son of a conference secretary," a position that sounds more bureaucratic than instructional. ${ }^{6}$ It would be interesting to know when his family came to Moscow, which housed a substantial foreign community since at least the mid-seventeenth century. Only Chistovich refers to Vien's cultural background in mentioning the German form of his name, Johann Wien. ${ }^{7}$ This is a potentially sensitive issue, in view of the supposed German domination of medical affairs in Russia throughout the eighteenth century and well into the nineteenth. The criticism of Vien by Chistovich and Soviet commentators may have resulted from this ethnic identification. In an era of rising Russian nationalism Chistovich often decried foreign influence in Russian medicine. Moreover, the Soviet criticism of Vien and lionization of Samoilovich both

\footnotetext{
${ }^{3}$ S. M. Grombakh, 'Danilo Samoilovich: zhizn' i deiatel'nost', in Danilo Samoilovich, Izbrannye proizvedeniia, edited by B. S. Bessmertny:, Moscow, Izdatel'stvo Akademii meditsinskikh nauk SSSR, 1952, vol. II, p. 435; K. G. Vasil'ev and A. E. Segal, Istoriia epidemii v Rossii: Materialy i ocherki, edited and supplemented by A. I. Metelkin, Moscow, Medgiz, 1960, p. 380, note 2.

‘ Tsentral'nyi gosudarstvennyi istoricheskii arkhiv SSSR, fond 1297, opis' 1, delo 21, pp. 108-109; f. 1297, op. 1, bk. 73, pp. 199v.-201; f. 1297, op. 1, bk. 71: 'Delo o pozhalovanii kollezhskogo sovetnika Viena $v$ statskie sovetniki', 4 August 1805, pp. 285-321v (hereinafter cited as TsGIA-SSSR) and Tsentral'nyi gosudarstvennyi arkhiv drevnikh aktov, gosarkhiv XVII, no. 124, pp. 1-2 (hereinafter cited as TsGADA).

${ }^{5}$ Chistovich, op. cit., note 2 above; B. N. Palkin, Russkie gospital'nye shkoly XVIII veka $i$ ikh vospitanniki, Moscow, Medgiz, 1959, appl I: 'Kratkii biograficheskii ukazatel' naibolee vydaiushchikhsia vrachei-vospitannikov gospital'nykh shkol XVIII veka', pp. 208-209.

'TsGIA-SSSR, f. 1297, op. 1, bk. 71, pp. 288-289.

${ }^{7}$ Chistovich, op. cit., note 2 above, p. cxxii.
} 


\section{Ivan Vien and the first comprehensive plague tractate in Russian}

bear the stamp of Stalinist antiwestern campaigns after World War II, a superpatriotic posture that has lasted longer in medical historiography than in other scholarly fields.

Upon closer study, Vien's ethnic identity proves to be quite complicated. Evidently a Russian citizen from birth, he lived his entire life within the empire. Still, he clung to the religion of his parents, presumably some form of Protestantism, most if not all of his life; for he remarked in his tractate of 1786 that he was non-Orthodox.$^{8}$ Nothing is known of his educational experiences before he entered the Moscow General Infantry Hospital and surgical school as a volunteer (i.e., non-scholarship student) in 1763 at the age of thirteen or fourteen, which fact hints at some precocity. Fluent from youth in German and Russian, Vien early acquired Latin - a prerequisite for medical study in eighteenth-century Russia - and by 1786 had also learned French and English. His writings included works in German, Latin, French, and Russian (see appendix). All of the records concerning his service career are in Russian, as one would expect, several with his signature in its Russian form, the only form I have found in original documents. In his professional life, then, it appears that Vien presented himself as Russian by culture. At least this was apparently the case by 1770, when he signed his "Russian" signature on a certification exam."

Vien entered state service officially on 3 December 1765 when he became a surgeon's mate (podlekar') at the Moscow hospital. Six months later he joined the Kazan musketeer regiment. Perhaps this assignment was intended to keep the young medic close to home; for his mother, possibly widowed, moved to Kazan some time before 1774 when she perished, together with her house and property, in the rebel Pugachev's surprise seizure and sack of the city in July $1774 .{ }^{10}$ After scarcely one year's duty in the field Vien was transferred to the St. Petersburg Admiralty Hospital where he was promoted to surgeon (lekar') on 23 July 1767. His future rival, Danilo Samoilovich, served there at the same time, so it is likely that the young men knew each other in that small medical community. ${ }^{11}$ The next three years found Vien in St. Petersburg, with a brief assignment to the fleet in 1769-70, before the medical demands generated by the Russo-Turkish War of 1768-74 facilitated his appointment as acting prosector at the St. Petersburg General Infantry Hospital on 9 September 1770. He had served less than four months in this post when the plague epidemic in the Ukraine caused his emergency assignment to the informal plague commission established by Empress Catherine II under Guards-Major Mikhail Shipov. "In his five year stay in the Ukraine" (actually, from 4 January 1771 to 8 December 1774), commented the compiler of Vien's service record, "he found himself constantly serving at the quarantine houses, cordon checkpoints, and pestilential hospitals." 12 Following

\footnotetext{
- Ivan Vien, Loimologia ili opisanie morovoi iazvy, eia sushchestva, proizshest viia, prichin, porazheniia $i$ proizvodstva pripadkov, s pokazaniem obraza predokhraneniia $i$ vrachevaniia seia skorbi, St. Petersburg, [printed by Her Imperial Majesty's order], 1786, p. 286.

${ }^{9}$ Correspondence of the State Medical Collegium, October 1770-1771, TsGADA, f. 344, op. 1, d. 42, p. 656.

10 Vien's service record, TsGIA-SSSR, f. 1297, op. 1, bk. 73, p. 199v.; his 1786 petition to Catherine II, TsGADA, gosark hiv XVII, no. 124, pp. 1-2.

${ }^{11}$ TsGIA-SSSR, f. 1297, op. 1, bk. 73, p. 194v.; Grombakh, op. cit., note 3 above, pp. 314, 368.

12 TsGIA-SSSR, f. 1297, op. 1, bk. 73, p. 200.
} 


\section{J. T. Alexander}

another year at the St. Petersburg General Infantry Hospital he gained an enviable position as surgeon to the Izmailovskii Guards Regiment, one of the élite corps stationed in the capital, wherein he served from 14 April 1776 until retiring from the military in 1789 to a post supervising the translation of foreign books at the Mining Institute (Gornyi korpus) in St. Petersburg. Service in the guards entailed a higher salary and better working conditions than in the regular army. During this period Vien published his magnum opus in $\mathbf{1 7 8 6}$ for which he was promoted to staff-surgeon (shtab-lekar'), the highest professional rank open to a practitioner without an M.D. Evidently because of his linguistic and research skills Vien became, on 5 April 1793, scholarly secretary of the Medical Collegium, the central administration for medical affairs. In June 1794, citing the precedents of his two predecessors in the post of scholarly secretary, Vien petitioned the empress to be made a member of the Medical Collegium as well. Catherine granted this request on 22 June 1794, and Vien held both positions until 1800 when he stepped down as scholarly secretary. His membership in the Medical Collegium ended in 1803 when it was absorbed into the new Ministry of Internal Affairs. Officially redundant (zashtatnyi) after 2 February 1804, Vien apparently pursued some of his scholarly work, either on an ad hoc basis or in his own time, but on 15 July 1804 Emperor Alexander I commissioned him to co-ordinate extraordinary antiplague efforts on the Caucasus military frontier. For executing this last commission Vien received a final promotion in service rank, in August 1805. He lived his final years in retirement and died in St. Petersburg in November 1809.13

II

Vien's service career offers some insight into the workings of the famous Table of Ranks as applied to an individual of foreign, non-noble background who had some special skills in a new profession of rising importance to state and society. According to the Table of Ranks as revised for medical practitioners in 1762, Vien as a surgeon's mate (1765-67) would have been in the fourteenth class, i.e., the lowest rung of the service ladder, with a yearly salary of 120 roubles and two rations. Promotion to surgeon (1767-86) would have raised him to the twelfth class with an annual salary of 180 to 300 roubles. ${ }^{14}$ Whatever his actual salary figure, it is probable that he received more than the minimum because of his special duties at the St. Petersburg General Infantry Hospital, his long and hazardous antiplague stint in the Ukraine - it was common practice to confer special rewards for such dangerous duties - and his lengthy attendance (1776-89) upon the Izmailovskii Guards. Indeed, this last post would have promoted him to the tenth class with a salary range of 250-300 roubles per year.

Perhaps Vien despaired of ever making staff-surgeon, which fell in the ninth class with a salary range of 400-600 roubles annually. At any rate, his next promotion came in the civil service when he was named titular councillor (ninth class) on 13 March 1779. ${ }^{15}$ It is unclear exactly what this step signified. Did he retire from the army

${ }^{13}$ Ibid., pp. 199v.-201; f. 1297, op. 1, bk. 71, pp. 298-299; Palkin, op. cit., note 5 above, p. 209.

14 Heinz E. Müller-Dietz, Ärtze im Russland des achtzehnten Jahrhunderts, Esslingen/Neckar, Robugen GmbH, 1973, pp. 68-69.

is TsGIA-SSSR, f. 1297, op. 1, bk. 73, p. 199v. 


\section{Ivan Vien and the first comprehensive plague tractate in Russian}

temporarily? That practice was not uncommon, but there is no hint of it in his service records. Did he buy a patent for the title? This was commonly done and involved no assignment to duty, but the more prestigious military titles were usually preferred..$^{16}$ However it was obtained, this title brought Vien, a commoner, to the threshold of hereditary nobility in the civil service. It should be noted that all fourteen ranks in the military conferred hereditary nobility, but only the top eight in the civil service. With the abolition in 1762 of compulsory state service for the nobility in peacetime, opportunities for civilian employment increased for former military practitioners, many of whom wished to avoid the rigours and isolation of field service in favour of private or public practice in the capitals or provincial towns. For reasons of general social prestige and for purposes of further advancement in the civil service, attainment of the eighth rank held great significance. In less than a year Vien made the crucial step to the eighth class when he gained - again, by means unknown - the title of collegiate assessor on 21 February 1780. Reaching the eighth class marked an important divide in the system of military ranks as well, because classes eight to six were considered "staff" grade, which implied considerably greater responsibilities." Presumably Vien's salary increased with each of these promotions.

Promotion to staff-surgeon in 1786 would not have improved Vien's service standing, inasmuch as that title was in the ninth class. But it represented a coveted professional plum, for there were few staff-surgeons as compared to hundreds of surgeons, and the rank may have radiated even greater prestige because few native-born surgeons had ever attained it."18 From personal, financial, and intellectual perspectives, moreover, Vien's achievement of this professional title entailed multiple rewards and opened new opportunities. Personally, it must have been deeply satisfying to be professionally rewarded for the publication of his magnum opus, the product of fifteen years' work and experience. The book brought him to the attention of Empress Catherine II herself. Like many other books of the time (including Samoilovich's tractate), it was dedicated to the empress. She approved its publication at state expense by the Academy of Sciences, personally thanked the author, and approved his petition that the state buy the 1,200 copies, which she paid for and then awarded to him. ${ }^{19}$ In petitioning the empress, Vien complained of having lost "everything" twice in his life - when his mother's house in Kazan was destroyed and, apparently, when he served against the plague in the Ukraine. He requested that the state purchase his book because it was not expected to sell well..$^{20}$ Actual sales remain unknown, but one may assume that it was distributed to most libraries, many government offices, and various medical institutions in Russia. ${ }^{21}$ Though the book obviously did not receive the recognition that Vien wished for, its publication benefited him directly in money terms and indirectly in career prospects.

\footnotetext{
16 James Hassell, 'Implementation of the Russian Table of Ranks during the eighteenth century', Slavic Review, 1970, 29 (2): 291.

${ }^{17}$ Ibid., pp. 284-285, 287-291.

18 M. Iu. Lakhtin, Etiudy po istorii meditsiny, Moscow, 1902, pp. 190-191.

19 TsGIA-SSSR, f. 1297, op. 1, bk. 71, pp. 286, 293, 309v.

20 TsGADA, gosarkhiv XVII, no. 124, pp. 1-2.

${ }^{21}$ For example, see Catalogus librorum Academiae Caesaraeae medico-chirurgicae, Petropoli, Typis Administrationis medicae, 1809, p. 327 ( 2 copies held).
} 


\section{J. T. Alexander}

On 31 December 1791, having left the army in 1789, Vien obtained the title of court councillor, which, like the one he already held, carried the eighth class. (Chistovich maintains that this title accompanied his appointment to the Medical Collegium in 1793, but his service record indicates otherwise.) Perhaps the new title simply marked another increase in pay, or perhaps an attempt by his employers to retain his services. Nevertheless, Vien was not satisfied with his position at the Mining Institute, for he sought the post of scholarly secretary of the Medical Collegium when the vacancy opened in $1793 .{ }^{22}$ His appointment doubtless owed much to Catherine's favour, her interest in fostering intellectual development and scholarly research, and her sceptical regard for academic formalities; Vien was the first and only non-M.D. to occupy the position. Since December 1792, in fact, Vien had been an honorary member of the Medical Collegium, a designation which indicated some status in high governmental and medical circles. Soon after becoming scholarly secretary, Vien petitioned Catherine to become a full member of the Medical Collegium, just as his predecessors, Drs. Pecken and Reinegs, had been. In support of his request he cited thirty-two years of service and Catherine's endorsement of his plague tractate - "a detailed composition, which was not the fruit of mere thinking, but of my own longterm, dangerous experience in infected localities." The empress approved his joint appointment on 22 June $1794 . .^{23}$

This double responsibility soon led to new troubles for Vien, who discovered that his predecessors had received much higher salaries for the two jobs $-1,500$ roubles for Pecken, 1,800 for Reinegs - whereas his own 1,000-rouble salary as scholarly secretary had not changed with the second appointment. ${ }^{24}$ Understandably, in the lengthy disputes that ensued over this matter, Vien ignored the fact that his predecessors had both been M.D.s. More surprising is that his employers also overlooked this difference, one of the fundamental distinctions in status, function, and training within all medical professions of the European type. The Medical Collegium refused Vien's request on grounds that it did not set pay scales and that his predecessors had received special pay because the general budget had not yet prescribed wages for the new post of scholarly secretary. ${ }^{25}$ Frustrated, Vien then petitioned Catherine directly, and she seems to have ruled in his favour; but the Medical Collegium still declined to raise his salary, alleging lack of specificity in the empress's order and that his appointment to the Medical Collegium had exceeded the positions budgeted ${ }^{26}$ This matter dragged on, unresolved, till almost the end of Vien's career in state service. It seems to have affected his whole outlook on service, and to have incited other discontents over rank, seniority, and perquisites. However depressing for Vien, the story yielded some rewards to historians inasmuch as his discontent prompted repeated approaches to his superiors that resulted in the compilation of a file on his case, a file which probably preserves the best record of his career and of his own view thereof.

\footnotetext{
${ }^{22}$ TsGIA-SSSR, f. 1297, op. 1, bk. 73, p. 200; bk. 71, p. 316.

${ }^{23}$ TsGIA-SSSR, f. 1297, op. 1, bk. 71, pp. 296v.-298.

${ }^{24}$ Chistovich, op. cit., note 2 above, pp. ccxlix, note 2 , cclxxiii.

${ }^{25}$ TsGIA-SSSR, f. 1297, op. 1, bk. 71, pp. 299-301.

${ }^{26}$ Ibid., p. $287 \mathrm{v}$.
} 


\section{Ivan Vien and the first comprehensive plague tractate in Russian}

On 2 May 1803 Vien addressed a lengthy petition, with seven appendices of supporting documentation, to Count V. P. Kochubei, the newly designated Minister of Internal Affairs under whose jurisdiction the Medical Collegium had been transferred. Vien's petition sought Kochubei's patronage to ameliorate "my straitened position" and expatiated upon complaints concerning decorations, rank, seniority, and salary. Repeatedly citing his forty years of service and diverse accomplishments, the petitioner argued, first, that he had earned the order of St. Vladimir for long and zealous service and noted sadly that his nomination for it in 1802 had been ignored. Second, he contended that he had been bypassed for promotion to the title of state councillor (fifth class) when others in the Medical Collegium with shorter service records at lower levels had already received that title. Third, he complained of being demeaned by his exclusion from the senior members of the Medical Collegium at the newly budgeted salary of 1,500 roubles per annum; he had been grouped with the junior members at an annual rate of only 1,200 roubles. Finally, as concerned salary, he argued that he had never been properly compensated for holding two responsible positions simultaneously and had lost, as a result, at least 300 roubles annually for a period of four years, "the return of which might restore my disordered poor fortune." His petition concluded with the usual fulsome promises of further zealous service to the emperor. ${ }^{27}$

The authorities looked into Vien's complaints and service record, noting that he was a bachelor and owned one male bondaged servant. By 9 September 1803 they decided that Vien merited some satisfaction in all areas except seniority. ${ }^{28}$ But when, nearly a year later, nothing had been done, Vien petitioned anew. His situation had worsened in the interim, he noted; final closure of the Medical Collegium had cut him adrift. "I have remained, as if undeserving of any attention, completely forgotten, so that I was not even deemed fit to be assigned to the membership of the Medical Council [of the Ministry of Internal Affairs], in which I prided myself in having sufficient right to be placed." Again he recounted his record: ten years in the Medical Collegium by imperial appointment, seven years as scholarly secretary, long state service, and - a new element - numerous "compositions published by me," a list of which he enclosed (see appendix). ${ }^{29}$ Apparently the medical authorities prepared a response, but either had second thoughts about it or, more likely, withheld their answer while Vien was away on the antiplague mission to the Caucasus. A draft of their response conceded his right to the Vladimir cross and agreed that his rank might be adjusted at the end of the year when a general review of officials would be undertaken. But the authorities declined to change Vien's duties, noting that the matter had been decided long ago and had been reviewed by the appropriate committees; in short, they offered the old man neither job nor money. ${ }^{30}$

In the late spring or early summer of 1805 Vien turned to Kochubei once more. Since returning to St. Petersburg four months before, he had received no answer to his

\footnotetext{
${ }^{27}$ Ibid., pp. 286-287v.

28 Ibid., pp. 288-289, 304-306.

29 Ibid., pp. 307-312.

30 Ibid., p. 314.
} 


\section{J.T. Alexander}

petition of 1803, no word about decorations or promotions, nor any recognition of his "responsible and important commission" to the Caucasus. He had been certain, he candidly declared, that successful fulfilment of the last commission would bring him due reward at last. In a final effort to refute rejection, he pointed out that he had left the "medical faculty" (i:e., active practice) more than sixteen years ago; hence the Senate prohibition of promoting medical ranks in the civil service should not apply in his case. ${ }^{31}$ Whether this last appeal softened the hearts of the authorities, or they simply decided to expedite the long delayed case, Vien's appeal was laid before Alexander I, who ruled on 1 August 1805 that recent and past service entitled him to promotion to state councillor (fifth class). The Senate transmitted this decision to Kochubei on 14 August 1805 with an order to inform Vien, to take his oath of obedience, and to collect the usual payment for promotion. ${ }^{32}$ So ended the case. Evidently Vien was not rehired, but the promotion may have improved his pension. One can only hope that he actually got the Vladimir cross. He certainly earned it.

\section{III}

From the discussion of Vien's professional and civil service careers it should be evident that his primary talents involved medical research and editorial activities. His list of works, some of which were never published, reveals that he was much more than the author of one now largely forgotten book. Indeed, he contributed much to the efflorescence of publication in Russia under Catherine II and Alexander I, a phenomenon that marked the inclusion of Russia into the European cultural world. ${ }^{33}$ Full entry into the cosmopolitan culture of Europe posed many dilemmas, of course, not the least of which were linguistic. Should Russian authors use only Russian, a tongue scarcely known in Europe, or should they employ the established European languages? This dilemma raised especially thorny problems in the fields of science and medicine, where Russia lacked a native tradition of scholarship and the language lacked essential terminology. ${ }^{34}$ To make rapid progress in medicine and to publicize Russia's progress in that field, it seemed prudent to master Latin first, but this had the undesirable side-effect of confining medical knowledge to a small élite, already remote from the bulk of the population. Practical medical advice for laymen and officials had to be in Russian. Multilingual by background and practitioner-oriented by professional experience, Vien was an ideal person to compose practical treatises in Russian, such as his plague tractate, and he also possessed the skills and official position to present Russian medical research in other languages.

In fact, Catherine II may have chosen Vien for the post of scholarly secretary of the Medical Collegium precisely to foster Russian medical research and publication. During his tenure (1793-1800) Vien devoted most of his time to organizing the Collegium's archives, soliciting manuscripts from practitioners interested in research,

\footnotetext{
31 Ibid., pp. 315-319v.

32 Ibid., pp. 320-321; Hassell, op. cit., note 16 above, p. 291.

${ }^{33}$ Gary J. Marker, 'Publishing and the formation of a reading public in eighteenth century Russia', unpublished Ph.D. dissertation, University of California at Berkeley, 1977.

${ }^{34}$ S. M. Grombakh, Russkaia meditsinskaia literatura XVIII veka, Moscow, Izdatel'stvo Akademii meditsinskikh nauk SSSR, 1953, pp. 60-64, 273-280.
} 
selecting the best works submitted, and preparing a collection of Russian medical commentaries for publication, as the charter of the Medical Collegium had promised in 1763. By way of reviving the project, Vien in 1794 issued an announcement calling upon all practitioners to submit scholarly works of research for review. He spent the next few years arranging publication of the first volume, which was originally to be issued in Russian and Latin, but finally appeared in 1805 only in Latin, at Vien's personal expense according to Palkin although that fact is not mentioned in the various promotion documentation..$^{35}$ Thus, Vien could properly claim credit for bringing to fruition a project conceived some forty years earlier. The volume had no direct sequels, unfortunately, although the original project had foreseen a regular series of such publications.

Vien's 1804 list of compositions (see appendix) enumerated sixteen items, but fully half of these were narrowly specialized, apparently short in length, and never published. Several of the published titles were also quite short or, in the case of the quarantine statute of 1800 , the product of joint authorship. Altogether different in size, scope, and style was Vien's principal work, Loimologia or a description of the pestilential distemper, its essence, occurrence, causes, affliction and of the production of symptoms, with a demonstration of the mode of preservation and treatment of this scourge (St. Petersburg, 1786). ${ }^{36}$ This substantial book, nearly 520 pages in octavo, deserves to be known as the first comprehensive plague tractate in Russian. The author himself certainly believed it was the main scholarly achievement of his career.

This tractate emerged from the discussions of plague provoked by the great epidemic of 1770-72, the later phases of which Vien had witnessed in the Ukraine in 1771-74. ${ }^{37}$ Like the treatises of other practitioners in Russia at the time, his manifested a strongly empirical and practical orientation. Divided into a "theoretical" and a "practical" part, the first was primarily addressed to other practitioners, the second to officials and educated laymen. The needs of the second audience dictated that his work be in Russian, to facilitate precautions and countermeasures against the constant threat of plague along the empire's southern borders.

In method Vien's work utilized a historical-critical approach laced with observations drawn from personal experience. Direct observation counted as the weightiest kind of evidence among most of the plague tractates produced in Russia in this general period, and several of Vien's predecessors in the field (e.g., Mertens, Orraeus, and Samoilovich) had seen more of the disease than he had, or had brought greater experience to their encounters with it. What distinguished Vien's work from theirs, however, was his extensive review of the European and Russian scholarly literature about plague. That is, Vien combined an emphasis on recent personal experience with a thorough, critical examination of the best plague authorities of the past. Other tractate writers stressed either their own observations or relied upon a few selected

\footnotetext{
${ }^{35}$ Palkin, op. cit., note 5 above, pp. 119-129. Curiously, Palkin never mentions Vien's ethnic background and even implies that he was Russian (p. 122).

${ }^{36}$ See note 8 above.

${ }^{37}$ For a general discussion of plague tractates from Russia, see J. T. Alexander, Bubonic plague in early modern Russia: Public health and urban disaster, Baltimore, Md., and London, Johns Hopkins University Press, 1980, chap. 11.
} 


\section{J. T. Alexander}

authorities. Considering Vien's modest professional status before his work appeared and his lack of foreign experience, the wide variety of writings that he consulted in five languages - Latin, French, German, English, and Russian - testified to enormous individual industry and to an impressive mastery of the main corpus of European and Russian plague research. At the very least his book was a major achievement of compilation that made the centuries-long European tradition of plague tractates available to a Russian audience. Furthermore, as concerned the shadowy history of plague in Russia before 1770, Vien may well have been the best-informed person inside the empire or out. His book incorporated a far larger historical dimension than most other tractates, European or Russian.

Contrary to champions of Samoilovich, Loimologia is not mainly a polemic against their hero. In some 520 pages there are only about ten explicit references to Samoilovich's writings. ${ }^{38}$ None is particularly caustic; several even with Samoilovich on the point in question. ${ }^{39}$ Vien and Samoilovich differed on only one major issue: the former favoured a primarily miasmatic concept of plague aetiology, whereas the latter endorsed a mostly contagionist perspective. But this apparent dichotomy shrinks into insignificance when one recognizes that both men shared vague miasmaticocontagionist premises. Both denied, for example, that the causative agent of plague was alive, but thought of it as an extremely subtle poison. In this regard their thinking was quite conventional, for the microscopic germ theory was then in general disfavour throughout the European medical world..$^{40}$

The principal disagreement between Vien and Samoilovich revolved around their attitudes toward previous scholarship. Clearly, Vien found Samoilovich's wholesale repudiation of earlier theorists unjustified and egotistical. He therefore delighted in puncturing a couple of Samoilovich's own grandiose claims to originality in the proposal of inoculations against plague and the novel therapy of ice massages. ${ }^{41}$ Moreover, Loimologia implicitly rejected Samoilovich's contemptuous criticism of previous authorities by presenting an extended discussion of many different theories. Study of plague in the past was practical and useful, Vien insisted, because the disease had not changed over time and analysis of past manifestations could lead to fuller knowledge of its nature in the present. ${ }^{42}$ In contrast to Samoilovich's aggressive advocacy of an extreme contagionist viewpoint, Vien took an explicitly eclectic approach that rejected no formulations completely except those deemed to be superstitious.

With Samoilovich, nevertheless, Vien also believed in the importance of recent, personal observation of plague, a position that he used to justify the appearance of his own account. At several points in the discussion he cited personal experience in buttressing his contentions. As examples of this technique, a favourite among most practitioner-tractate authors, Vien argued that children were less vulnerable to plague

\footnotetext{
38 Vien, op. cit., note 8 above, pp. 90, 120, 149, 156, 160, 203, 246, 286, 373, 435.

39 Ibid., pp. 203, 246, 286.

${ }^{40}$ L. F. Hirst, The conquest of plague, Oxford, Clarendon Press, 1953, pp. 46, 52-62, 80

${ }^{41}$ Vien, op. cit., note 8 above, pp. 373, 435 .

42 Ibid., p. $6 \mathrm{ff}$.
} 
by remarking that in the recent epidemic he had not seen a single very young person infected; he also asserted that women had greatly outnumbered men as plague victims, but quoted no statistics in support of this claim (which is rather implausible, according to other statistics of the time and more recent research).$^{43}$ In addition, noting the difficulty of accurately diagnosing plague, Vien recounted a case in Kiev where a woman had been pronounced infected by a senior practitioner, but young Vien had discovered that she was pregnant, not sick, and had insisted upon her return to town from a suburban quarantine. Unfortunately, the woman was returned too late to prevent a miscarriage and the death of two companions from exposure and poor lodgings. ${ }^{44}$ It is not possible to offer independent verification of such accounts, which were obviously intended to enhance the author's credibility. Samoilovich and others employed such personal testimony on a considerably wider scale than did the more modest Vien.

To conclude about the value of Loimologia, there is no point in making any grand claims for this particular treatise. In the long European tradition of plague theorizing, Vien's book formed one small link of a chain that ultimately led to the unravelling of the mysteries of bubonic plague. In the much shorter Russian tradition, however, it bulks larger and properly merits recognition as the first comprehensive plague tractate in Russian, an important book in its time that has been unjustly forgotten. Even less does its author deserve oblivion. His career offers a vivid example of social advancement under the tsarist regime, of talent and persistence rewarded (partly through imperial favour). In many respects Ivan Vien exhibited all the attributes that Empress Catherine II strove to cultivate in her educated subjects: "enlightenment" applied to a practical field badly needed by society, self-advancement in a new European-type profession by a commoner of cosmopolitan background, and consciously patriotic Russian literary activity in a new scholarly sphere valued in Europe and now developing in Russia. His career demonstrated, too, that it was possible for a Russian citizen to achieve a creditable level of scientific knowledge and professional status without ever leaving the country or attending a university. His varied activities and works in several languages suggested some of the creative potential fostered by the culturalethnic interpenetration within the hybrid Russo-German medical community of early modern Russia. National antagonisms sometimes arose from these cultural encounters, but so did russified achievements like those of Ivan Vien.

\section{APPENDIX: COMPOSITIONS OF IVAN VIEN (1804)}

1. Ten medico-practical observations that confirm the useful inoculation of Field Scabious [Knautia arvensis] for the treatment of those suffering from dropsy - submitted to the Medical Collegium in Russian in 1768.

2. Experiments successfully performed by me upon two boys of the former president of the Collegium Baron Cherkassov, deaf from birth, concerning the mode of teaching to pronounce Russian letters according to Aman's method - submitted to the Collegium in Russian in 1769.

\footnotetext{
${ }^{43}$ Ibid., p. 206; Alexander, op. cit., note 37 above, chap. 10.

44 Ibid., pp. 255-256.
} 


\section{J. T. Alexander}

3. An anatomico-physiological description of a human monster, headless from birth, submitted to the Collegium in Latin in 1770 along with four drawings, a duplicate of which was then transmitted by professor of anatomy Mellen, because of the subject's rarity, to the Swedish Academy for inclusion in its proceedings.

4. A brief outline of the Kiev pestilential distemper and the mode of my treatment, sent to the Collegium in German in 1772.

5. A complete meteorological table compiled by me in Kiev through the entire year 1772 showing the harmful changeable constitution of the atmosphere, which strongly facilitated the distribution of infection at the time, sent to the Collegium in 1773.

6. Concerning the critically necessary use occasionally of the most powerful doses of vinegars, to revive depressed forces of life, on the occasion of the description of the illness of former governor-general of Kiev Voeikov, sent to the Collegium in Latin in 1774.

7. A description of the operation fortunately performed by me on the guidon assistant of the Nezhin regiment, Trupchenkoi, for cataract according to the Davliev method, sent to the Collegium in German in 1775.

8. An observation concerning the extremely difficult births of a woman who lived in the Podol [at the house of?] the Greek merchant Anastazii, and concerning the means employed by me for stimulation of the womb and incitement of birth pangs, sent to the Collegium the same year in Russian.

9. An observation confirming the advantageous use of forced air, as an extremely powerful means of fighting corruption, on the occasion of an operation performed by me to amputate the thigh of a noncommissioned officer of the Izmailovskii Lifeguards Regiment, sent to the Collegium in Russian in 1780.

10. Loimologia or a description of the pestilential distemper, its essence, occurrence, causes, affliction and production of symptoms, with a demonstration of the means of preservation and treatment of this scourge - this fruit of my five years' stay in places ravaged by it and then the work of ten years in composition, having come to the monarchical attention of the great CATHERINE, was by HER most gracious personal order printed at government expense at the Academy of Sciences in 1786. For this work of mine I was made happy by the MONARCH's oral good wishes, a money reward, and the award to me of all 1,200 copies.

11. A dissertation concerning the influence of anatomy on sculpture and painting, written by me at the wish of the late Ivan Ivanovich Betskoi for the use of the pupils of the Academy of Arts, printed by Schnor in 1789.

12. Medico-practical remarks relating to the useful and the harmful use of cold baths with the attachment of a sketch showing their principal features; and likewise the sicknesses for the treatment of which they are suitable - printed in French at the Mining Institute in 1791.

13. The statute of port and border quarantines, drafted by three members of the Medical Collegium among whom I actively co-operated because of my experience relating to this subject - published [in Russian] in 1800.

14. A historical review of sculpture and painting with a full demonstration of the powerful influence of anatomy in these two liberal arts, explicated with evidence taken from traditions of art and from actual experience, according to the extant creations of 
the most celebrated artists of past centuries and of our times. This creation, dedicated to His Imperial Majesty and given by me for presentation to His Excellency Count Viktor Pavlovich Kochubei, was printed at the press of the State Medical Collegium in 1803.

15. The first volume of practitioners' observations and inventions of Russian practitioners, edited by me in Latin and ready in manuscript from 1799, now being printed under my supervision at the press of the State Medical Administration, and of which eight printed galley proofs have already come off the press.

16. Presently I am likewise occupied to the benefit of my fellow-countrymen in composing rules and a demonstration of the mode of teaching persons, deaf from birth, to read, write, and speak Russian, following the Aman method as the most perfected one.

\section{SUMMARY}

Using fresh information from archives in the Soviet Union, this paper reconsiders the life and writings of Ivan Vien (c. 1750-1809), a little-known German-Russian practitioner whose diverse activities included composing the first comprehensive plague tractate in Russian, published in 1786 with the personal authorization of Empress Catherine II. The issue of Vien's nationality is examined in the context of the Europeanization of Russian culture under Catherine II, the emergence of a modern medical profession in Russia, and the nationalistic and social tensions that affected the Russian medical profession and its historians in Imperial Russia and the Soviet Union. Vien's life, professional career, and bureaucratic service are presented as an example of great social advancement by a commoner of foreign background. Despite limited formal and professional training, he capitalized upon linguistic talents to write numerous works in several languages, the most significant being his plague tractate, which won him the empress's favour and considerable stature in the Russian medical world of his time. His tractate is briefly discussed in comparison to others produced in Russia at the time. It is contended that Vien's tractate compares favourably with its Russian and European predecessors, and that it represented an important compendium of previous scholarship critically considered, laced with personal observations, and made available for the first time to a Russian audience. An 1804 list of his compositions is appended. In sum, Vien is seen to be an important figure in the history of medicine in Russia and in the history of Russian research concerning bubonic plague.

\section{ACKNOWLEDGEMENTS}

For research support I am indebted to the National Library of Medicine, U.S. Public Health Service, grants 1 R01 LM 01664 and 1 R01 LM 02359, to the International Research and Exchanges Board, the U.S.S.R. Ministry of Higher and Specialized Secondary Education, and the General Research Fund of the University of Kansas (award no. 3276). 